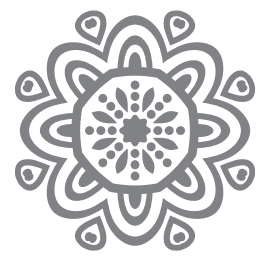

\title{
PENDEKATAN ILMU KOMUNIKASI MODERN Sebuah Metodologi Tafsir Al-Qur'an Kontemporer
}

\author{
M. Akib
}

\begin{abstract}
: the science is real communication has a strong scientific foundation, as derived from the Qur'an. Through Qur'an bersosial people are invited to live and communicate. In this case the Qur'an gives positive values yag should be developed and when talking about the concept of science communication in the Qur'an implies how the Qur'an describes the concepts of Islamic communication based content in it, This thesis also explains that the decline in the Qur'an as the word of God to men is according to man's knowledge of the communication. It follows that the Qur'an is indeed very appropriate and certainly fits the human ability. From these results it can be concluded with a diagram that explains the mutual communication between modern science with the explanation of the Qur'an.
\end{abstract}

Keywords: communication, method, Al-Qur'an, Approach

\section{Pendahuluan}

Penafsiran Al-Qur’an dengan tujuan mencari pengertian yang lebih jelas dalam kaitannya dengan hidup dan kehidupan manusia telah cukup banyak dilakukan, dengan berbagai metode atau cara yang melatarbelakanginya, baik berdasar kaidah bahasa, sejarah, filsafat, tasauf dan sebagainya. Semua itu pada hakikatnya untuk mendapatkan penjelasan yang konkrit dan mengena dalam rangka menjawab tantangan zaman yang dihadapi oleh umat manusia sepanjang sejarah sejak Al-Qur'an di turunkan.

Kajian tentang Al-Qur'an dalam khazanah intelektual Islam memang tidak pernah berhenti. Setiap generasi memiliki tangung jawab masing-masing untuk menyegarkan kembali kajian sebelumnya, yang di anggap ketinggalan zaman. Kemunculan metode tafsir kontemporer diantaranya dipicu oleh kekhawa- 
tiran yang akan ditimbulkan ketika penafsiran Al-Qur`an dilakukan secara tekstual, dengan mengabaikan situasi dan latar belakang turunnya suatu ayat sebagai data sejarah yang penting. ${ }^{1}$

Ulama-ulama salaf terdahulu, telah membentuk suatu metodologi sebagai upaya mendialogkan Al-Qur'an dan hadis dengan konteks mereka. Namun, ketika dibawa kepada konteks yang berbeda, metodologi itu tidak mampu lagi mendialogkan keduanya sebagaimana kebutuhan konteks yang baru. Untuk menjadikan keduanya terus berbicara, maka dibutuhkan metodologi baru yang bisa mengakomodasi perkembangan zaman sehingga keduanya menjadi elastis dan fleksibel. Dan hermeneutik, sebagai kajian interpretasi teks yang berasal dari Barat, mengundang perhatian dikalangan para pemikir Islam untuk menjadikannya sebagai kajian terhadap Al-Qur'an dan hadis. ${ }^{2}$

Pada mulanya usaha penafsiran ayat-ayat Al-Qur'an berdasarkan ijtihad masih sangat terbatas dan terikat dengan kaidah-kaidah bahasa serta arti-arti yang dikandung oleh satu kosakata. Namun sejalan dengan lajunya perkembangan masyarakat, berkembang dan bertambah besar pula porsi peranan akal atau ijtihad dalam penafsiran ayat-ayat Al-Qur'an, sehingga bermunculanlah berbagai kitab atau penafsiran yang beraneka ragam coraknya.

Corak-corak penafsiran yang dikenal selama ini antara lain: (a) Corak sastra bahasa, yang timbul akibat banyaknya orang non-Arab yang memeluk

\footnotetext{
${ }^{1}$ Metode tafsir kontemporer adalah, metode penafsiran Al-Qur'an yang menjadikan problem kemanusiaan yang ada sebagai semangat penafsirannya. Persoalan yang muncul dihadapan dikaji dan dianalisis dengan berbagai pendekatan yang sesuai dengan problem yang sedang dihadapinya serta sebab-sebab yang melatar belakanginya. Survei yang dilakukan Jansen terhadap corak pemikiran mufassir modern memperlihatkan pada tiga peta pemikiran, yaitu corak pemikiran tafsir Ilmi, tafsir Filologi, dan tafsir Adabi Ijtima i. http://dakwahsyariah.blogspot.com /2014/01/tafsir-kontemporer-dan-penjelasannya.html, Di akses 19 Mei 2016
}

${ }^{2}$ Dari definisi yang telah penulis kemukakan, dapatlah ditarik sebuah pengertian bahwa hermeneutik adalah suatu ilmu yang mencoba menggambarkan bagaimana sebuah kata atau suatu kejadian pada waktu dan budaya yang lalu dapat dimengerti dan menjadi bermakna secara eksistensial dalam situasi sekarang. Dengan kata lain, hermeneutik merupakan teori pengoperasian pamahaman dalam hubungannya dengan interpretasi terhadap sebuah teks. Dalam hal ini ada 3 unsur/ pilar utama hermeneutik, yaitu: (1) Penggagas, (author) komunikator atau subjek yang menyampaikan apa yang ada dalam benaknya dan hendak disampaikan kepada audiens melalui bahasa; 2) Teks (text), bahasa yang menjadi alat penyampaian, yang menjadi tanda bagi maksud ujaran tersebut; 3) Pembaca (reader), atau audiens yang menjadi sasaran pengujaran komunikator.

Namun dalam kajian hermeneutik, bukan hanya gramatika bahasa yang ditekankan, pendekatan historis, sosiologis dan antropologis juga harus dikedepankan. Dengan begitu, untuk mengetahui pesan-pesan yang ada dalam teks, harus diketahui latar belakang sosial budaya dimana dalam situasi apa sebuah teks itu muncul. Lihat Yunahar Ilyas dan M. Mas'udi, Pengembangan Pemikiran Terhadap Hadis, Yogyakarta: LPPI, 1996, hal. 3-4, dan Aksin Wijaya, Arah Baru Studi Ulûm Al-Quran: Memburu Pesan Tuhan di Balik Fenomena Budaya, Yogyakarta: Pustaka Pelajar, 2009, hal. 179. 
agama Islam, serta akibat kelemahan-kelemahan orang Arab sendiri di bidang sastra, sehingga dirasakan kebutuhan untuk menjelaskan kepada mereka tentang keistimewaan dan kedalaman arti kandungan Al-Qur'an di bidang ini. (b) Corak penafsiran ilmiah, akibat kemajuan ilmu pengetahuan dan usaha penafsir untuk memahami ayat-ayat Al-Qur'an sejalan dengan perkembangan ilmu. (c) Corak fiqih atau hukum, akibat berkembangnya ilmu fiqih, dan terbentuknya mazhab-mazhab fiqih, yang setiap golongan berusaha membuktikan kebenaran pendapatnya berdasarkan penafsiran-penafsiran mereka terhadap ayat-ayat hukum. (e) Corak selanjutnya yakni lebih terfokus pada sastra budaya kemasyarakatan. Yakni satu corak tafsir yang menjelaskan petunjuk ayat-ayat Al-Qur'an yang berkaitan langsung dengan kehidupan masyarakat, serta usaha-usaha untuk menanggulangi penyakit-penyakit atau masalah-masalah mereka berdasarkan petunjuk ayat-ayat, dengan mengemukakan petunjuk-petunjuk tersebut dalam bahasa yang mudah dimengerti tapi indah didengar. Salah satu tokoh corak ini ialah Syaikh Muhammad «Abduh (1849-1905 M). ${ }^{3}$

Secara metodologis upaya memahami Al-Qur'an dilakukan dengan tiga tahap, yaitu penentuan problem pemahaman ayat yang diselesaikan, penentuan pendekatan yang relevan bagi solusi problem yang bersangkutan beserta teknik aplikasinya, dan pengambilan kesimpulan dengan mengungkap petunjuk dan pelajaran dari ayat yang bersangkutan. Sebagai penyempurna langkah-langkah tersebut dapat dilakukan perumusan petunjuk secara kontekstual untuk menjawab persoalan yang muncul pada kurun waktu yang bersangkutan atau sebagai langkah antisipasi bagi persoalan yang mungkin akan muncul pada masa yang akan datang. ${ }^{4}$

Jika melihat semua kenyataan ini secara menyeluruh maka akan timbul pertanyaan, Apakah Al-Qur'an demikian sulitnya sehingga tidak dapat dicerna oleh semua orang dengan mudah?. Jawabannya sudah tentu: "Tidak". Karena Al-Qur'an sendiri menyatakan bahwa Al-Qur'an diturunkan dalam bahasa Arab agar manusia sendiri mudah memahaminya. ${ }^{5}$

${ }^{3}$ M. Quraisy Shihab, Membumikan Al-Qur'an, Bandung: Mizan, 1998, hal. 73.

${ }^{4}$ Penyelesaian setiap problem pemahaman memerlukan sejumlah pendekatan yang relevan dan teknik benar. Pendekatan-pendekatan dalam membahas ayat dan menyelesaikan problem pemahaman makna leksikal adalah dengan ilmu șarf, syair-syair dan kata-kata mutiara Arab Jahiliah, kamus-kamus bahasa Arab dan ensiklopedia Arab klasik, keterangan para sahabat dan para periwayat hadis, serta keterangan ahli di bidangnya. Pendekatan-pendekatan dalam menyelesaikan problem pemahaman struktur kalimat dan makna gramatikalnya adalah ilmu nahw dan ilmu balâghah. Pendekatan-pendekatan dalam menyelesaikan problem pemahaman petunjuknya adalah al-Qawầid al-Ușhûliyyah, Maqâsid al-Syarîah, dan al-Qawẩid al-Fiqhiyyah. Lihat Mujiyo, "Syarah Hadis dalam Tradisi Keilmuan Islam: Genealogi dan Metodologi”, Disertasi: UIN Syarif Hidayatullah Jakarta, 2010, hal. 249.

${ }^{5}$ Firman Allah SWT:

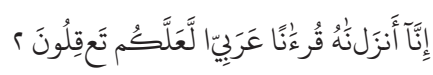


Dengan demikian menurut logika ayat Al-Qur'an bahwa permasalahannya adalah pada manusia itu sendiri yang membuat dirinya menjadi sulit dalam memahami ayat-ayat Allah. Manusia sendirilah yang barangkali telah membuat berbagai kriteria penafsiran, yang meskipun dalam rangka untuk kemudahan namun semakin menyulitkan dalam kenyataannya.

Banyak sekali ayat-ayat yang hanya dipahami sebatas cerita fantasi spekulatif, seperti ayat tentang fadhilah membaca surat al-Fâtihah kepada yang telah meninggal dunia dalam tradisi tahlilan. Pemahaman seperti ini kurang kalau tidak dikatakan tidak sama sekali mendidik kecerdasan intelektualitas manusia, padahal Al-Qur'an esensinya adalah petunjuk bagi hati, pikiran dan perasaan manusia untuk dimengerti kemudian untuk dapat diterapkan dalam kehidupannya sehari-hari.

Rekonstruksi penafsiran ayat Al-Qur'an yang mungkin berbeda dengan metode yang dipakai oleh ulama lain, dan semakin berkembangnya zaman maka berkembang pula ilmu pengetahuan, maka semakin komplitlah permasalahan yang dihadapi pada masa modern ini. Seperti hal dalam memahami ayat, metode-metode lama ${ }^{6}$ untuk memahami Al-Qur'an dianggap kurang relevan dalam menjawab permasalahan kekinian. ${ }^{7}$ Karena itu, perlu ada pendekatan lain seperti tinjauan ilmu komunikasi modern.

Secara tidak langsung penelitian ini ingin menegaskan bagaimana supaya Al-Qur'an dapat dipahami oleh setiap manusia terutama umat Islam sesuai dengan tingkat kemampuannya berkomunikasi dengan Allah? Dengan tidak terlalu terkait dengan kriteria-kriteria yang sangat ketat yang telah di tetapkan oleh sebagian ulama tertentu. Dimana kriteria tersebut tidak semua manusia mampu memahaminya. Tapi berbeda dengan 'komunikasi' semua manusia melakukannya meskipun sebagian manusia tidak mengetahui ilmu komunikasi secara teoritis tapi menjadi pengalaman hidupnya sehari-hari.

Artinya: Sesungguhnya Kami menurunkannya berupa Al-Qur'an dengan berbahasa Arab, agar kamu memahaminya. (QS. Yusuf/12:2)

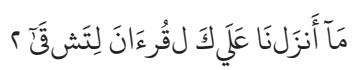
Thâha/20:2)

Artinya: Kami tidak menurunkan Al-Qur'an ini kepadamu agar kamu menjadi susah. (QS.

${ }^{6}$ Empat metode yang lazimnya digunakan yaitu: metode tahlîlî, ijmâlî, maudhû̀' dan $m u$ qâran. Keempat metode ini pada dasarnya juga bisa digunakan dalam memahami ayat Al-Qur'an. Nashrudin Baidan, Metodologi Penafsiran Al-Quran, Yogyakarta: Pustaka Pelajar, 2000, hal. 151.

${ }^{7}$ Yusuf al-Qaraḍ̂̂î̂, al-Khashâiș wa al-Hayât al-Mu'âșyirah, Kairo: Dar al-Ma'rifah, t.t, hal. 220-221; Musțafa al-Sibâî̀, as-Sunnah an-Nabawiyyah wa Makânatuha fî at-Tasyrî̀ al-Islâmî, Beirut: al-Maktab al-Islâmi, 1976, hal. 285; dan Hasbi ash-Shiddiqi, Pokok-Pokok Ilmu Dirayah Hadis, Jakarta: Bulan Bintang, 1976, hal. 128. 
Dalam hal ini kalau kita ingin sepakat tentang satu kriteria yang dapat diterima oleh setiap manusia yang ingin menafsirkan Al-Qur'an adalah tujuannya karena Allah, sehingga kalaupun salah dalam upaya berijtihad menafsirkan atau memahami Al-Quran, maka ia tetap mempunyai nilai dimata Allah.

Sementara Al-Qur'an sendiri memberi peluang kepada setiap manusia untuk dapat berinteraksi dengannya sesuai dengan kekuatan nalar masing-masing manusia sebagai konsekuensi dari pada Al-Qur’an sebagai petunjuk bagi manusia seluruhnya.

Penelitian ini bertujuan agar dapat melakukan terobosan baru dalam metodologi penafsiran Al-Qur'an yang berbeda dengan metode yang sudah ada sebelumnya.

Tentu saja peneliti berharap bahwa adanya metode ini tidak mengurangi nilai metode yang sudah ada sebelumnya tapi saling melengkapi dan mendekatkan kepada pemahaman yang rasional terhadap Al-Quran, tanpa mengesampingkan arti pentingnya intuisi hati nurani yang dapat merasakan kebenaran Al-Qur'an.

Dengan ilmu komunikasi kita dapat menggunakannya untuk dapat mempengaruhi jiwa manusia mengenal Allah dan memahami pesan-pesan Nya yang terdapat di dalam Al-Quran.

Peneliti berharap metode ini mempunyai nilai akademis yang dapat memberikan informasi dalam menambah khazanah keilmuan Al-Qur’an (Ulûm al-Qurân).

\section{Metodologi Tafsir Kontemporer}

Sebagai sebuah disiplin ilmu, tafsir tidak terlepas dari metode, yakni suatu cara yang sistematis untuk mencapai tingkat pemahaman yang benar tentang pesan Al-Qur'an yang dikehendaki Allah. Dengan demikian, metode tafsir dapat diartikan sebagai suatu prosedur sistematis yang diikuti dalam upaya memahami dan menjelaskan maksud kandungan Al-Qur'an. Menurut Baidan metode tafsir merupakan frame kerja yang digunakan dalam menginterpretasikan pesan-pesan Al-Qur'an, sedangkan metode tafsir adalah analis ilmiah mengenai metode-metode penafsiran Al-Qur'an. ${ }^{8}$ Dari sini dapat disimpulkan bahwa me-

${ }^{8}$ Nashruddin Baidan, Metodologi Penafsiran Al-Quran, Jakarta: Pustaka Pajar, 1998, hal. 2. Penggunaan kata metodologi dan metode seringkali disamakan dalam sebuah karya tulis, seperti penggunaan metode penelitian dan metodologi penelitian, walaupun pada dasarnya dua istilah tersebut memiliki esensi yang berbeda sebagaimana pernah dijelaskan pada pengertian metode dan metodologi secara etimologi. Namun sebagai perbandingan yang lebih jelas lagi, penulis paparkan perbedaan antara metodologi penelitian dengan metode penelitian. Menurut Noeng Muhadjir, se- 
todologi tafsir kontemporer adalah merupakan kajian di sekitar metode-metode tafsir yang berkembang pada era kontemporer.

Apabila ditelusuri sejarah perkembangan tafsir, terutama awal Islam, tidak ditemukan secara spesifik penjelasan dan pemilihan aspek metodologis tafsir Al-Quran. Ini mungkin dikarenakan, pertama, wacana metodologi tasir termasuk hal yang "baru didiskusikan" dan terutama dikembangkan ketika terjadi persentuhan antara tradisi Islam dengan peradaban Barat modern yang diklaim handal dalam metodologi. Kedua, para ulama mempunyai terminologi yang berbeda dalam memandang dan menilia objek kajian tafsir, termasuk dalam persoalan metodologi penafsiran Al-Qur'an. Di antara mereka, misalnya, ada yang merujuk kepada tradisi ulama salaf dan ada pula yang merujuk pada temuan ulama kontemporer.

Adapun metode tafsir yang merujuk kepada tradisi ulama salaf dalam menafsirkan Al-Qur'an adalah: (1) tafsir berdasarkan riwâyah yang disebut attafsîr bi al-ma'tsûr; (2) tafsir berdasarkan dirâyah yang dikenal dengan at-tafsîr bi al-ra'y atau bi al-ijtihâd; dan (3) tafsir berlandaskan isyarat yang populer dengan nama at-tafsîr al-isyârî. ${ }^{9}$

mentara orang tidak peduli dan mencampur-baurkan antara metode penelitan dengan metodologi penelitian, sehingga sering dijumpai adanya tulisan yang judul babnya "Metodologi Penelitian", namun subtansi bahasannya tentang "Metode Penelitian". Apa perbedaannya? Metodologi penelitian mengkaji konsep teoritik berbagai metode, kelebihan dan kelemahannya, yang dalam karya ilmiah dilanjutkan dengan pemilihan metode yang digunakan. Sementara metode penelitian membahas secara teknis tentang metode-metode yang digunakan dalam suatu penelitian. Lihat, Noeng Muhadjir, Metodologi Penelitan Kualitatif, Yogyakarta: Rake Sarasin, 2000, edisi ke-4, hal. 3.

${ }^{9}$ Hasan Yunus 'Ubaidû, Dirâsât wa Mabâhits fi Târîkh at-Tafsîr wa Manâhi al-Mufasirîn, Kairo: Markaz al-Kitâb li an-Nasyr, 1991, hal. 18. Untuk memperjelas persoalan, penulis paparkan definisi masing-masing metode tafsir yang berdasarkan pada sumber rujukan penafsirannya. Pertama, at-tafsîr bi al-Ma'tsûr adalah penafsiran makna ayat-ayat Al-Qur'an berdasarkan ayat Al-Qur'an lainnya atau berikutnya. Bentuk ini merupakan cara penafsiran yang paling baik dan reliable. Termasuk dalam kategori ini adalah penafsiran Al-Qur'an berdasarkan sunnah yang sahih, atau pedapat sahabat. Kedua, at-tafsîr bi ar-Ra'y adalah penafsiran Al-Qur'an berdasarkan hasil ijtihâd seorang mufasir yang memiliki kemampuan dalam memahami bahasa Arab dan gaya bahasanya serta aspek terkait lainnya seperti asbâb an-nuzĥl, nâsikh mansîkh, dan sebagainya. Ketiga, at-tafsîr al-isyârî adalah penafsiran Al-Qur'an yang mengacu pada pentakwilan ayat dengan sesuatu yang berbeda dengan makna lahiriyah ayat, karena adanya isyarat-isyarat implisit yang dijumpai oleh mufasir penganut suluk dan tasawuf. Lihat Hasan Yunus 'Ubaidû, Dirâsât wa Mabâhits..., hal. 20, 24-25. Dalam penafsiran dikenal pula apa yang disebut tafsir yang terpuji (at-tafsîr al-mahmûd) dan yang tercela (at-tafsîr al-madzmûm). Tafsir yang terpuji meliputi: (1) tafsir sahabat dan tabi'in; (2) tafsir yang bersandar pada perkataan sahabat dan tabi'in dengan mata rantai (sanad) yang sahih; dan (3) tafsir ahli ra'yi (berdasarkan ijtihad) yang disepakati, yang menghimpun antara riwayat sahih dengan meng-eliminir sanadnya dan menjelaskan pendapat-pendapat ilmiah mereka yang moderat. Sementara tafsir yang tercela adalah tafsir para ahli yang cenderung emosional dan bernuansa inovatif (bid'ah). Para ulama menganggap tafsir ini sesat dan mengatributkannya kepada karya-karya yang ditulis oleh tokoh alirann Mu’tazilah seperti, ar-Rummânî (w. 384 H), Abû 'Alî al-Jubbầî (w. 303 H) dan Qâdhî ‘Abd al-Jabbâr (w. 415 H). Lihat az-Zarqânî, Manâhil al-Irfân..., Jilid 2, hal. 42. 


\section{Pendekatan Ilmu Komunikasi dalam Penafsiran Al-Qur'an}

Kajian ilmu komunikasi perspektif Al-Qur'an dapat menggunakan metode tafsir tematik (maudî̀i), yaitu suatu metode kajian topik tertentu berlandaskan Al-Qur'an.

Sebagaimana yang telah dijelaskan di atas bahwa Secara umum, metode tematik memiliki dua bentuk kajian, yaitu: Pertama, pembahasan menyangkut satu surat Al-Qur'an secara utuh dan menyeluruh dengan menjelaskan maksudnya yang umum dan spesifik, menerangkan kaitan antara berbagai persoalan yang dimuatnya sehingga surat itu tampak dalam bentuknya yang utuh dan cermat. Dalam hal ini mufasir hanya menyampaikan pesan yang dikandung dalam satu itu saja.

Kedua, mengoleksi sejumlah ayat dari berbagai surat yang membahas satu persoalan tertentu yanng sama, lalu ayat-ayat itu ditata sedemikian rupa dan diletakkan di bawah satu topik bahasan, dan selanjutnya ditafsirkan secara tematik. Betuk ini lahir atas kesadaran para pakar Al-Qur'an bahwa menafsirkan pesan yang dimuat dalam satu ayat saja acapkali tidak menyelesaikan persoalan.

Dalam pembahasan ini maka metode yang digunakan dalam pendekatan komunikasi dalam penafsiran Al-Qur'an adalah dengan mengumpulkan ayat-ayat yang berkaitan dengan komunikasi. Berbicara tentang komunikasi berarti berbicara mengenai bahasa. Hal ini dikarenakan komunikasi dan bahasa merupakan satu kesatuan yang tidak dapat dipisahkan (bersifat komplementer). Bahasa merupakan salah satu hasil kebudayaan manusia yang terpenting dalam peradabannya.

Dalam sebuah ungkapan Arab disebutkan al-kalamu shifatul mutakallim artinya ucapan atau perkataan menggambarkan si pembicara. ${ }^{10}$ Dari pernyataan ini dapat dipahami bahwa perkataan/ucapan atau dengan istilah lain kemampuan berkomunikasi akan mencerminkan apakah seseorang terpelajar atau tidak. Dengan demikian berkomunikasi bukanlah hanya identik dengan menyampaikan sebuah informasi.

Demi terciptanya suasana kehidupan yang harmonis antar anggota masyarakat maka harus dikembangkan bentuk-bentuk komunikasi yang beradab hal ini sebagaimana digambarkan oleh Jalaluddin Rahmat yaitu sebuah bentuk komunikasi di mana 'sang komunikator' akan menghargai apa yang mereka hargai, ia berempati dan berusaha memahami realitas dari perspektif mereka. Pengetahuannya tentang khalayak bukanlah untuk menipu tetapi untuk memhami mereka dan bernegosiasi dengan mereka serta bersama-sama saling memulia-

${ }^{10}$ Al-Sakhawi, Al-Maqâshid al-Hasanah, (Beirut: Dar al-Hijrah, 1986), h. 31. 
kan kemanusiaannya. Adapun gambaran kebalikannya yaitu apabila sang komunikator menjadikan pihak lain sebagai objek ia hanya menuntut agar orang lain bisa memahami pendapatnya. Sementara itu, ia sendiri tidak bisa menghormati pendapat orang lain. Dalam komunikasi bentuk kedua ini bukan saja telah men-dehumanisasikan (melecehkan nilai kemanusiaan) mereka tetapi juga dirinya sendiri. ${ }^{11}$

Dalam Al-Qur'an istilah komunikasi sebagian besar diungkapkan dengan kata قال-نطق- كلم- تكلم. kesemuanya memiliki derivasinya, seperti kalimat "Qâla diulang sebanyak 1722 kali yang terdapat pada 141 ayat ${ }^{12}$ dalam 57 surat, kata Nathaqa dengan berbagai derivasinya diulang sebanyak 12 kali yang terdapat pada 16 ayat dalam 11 surat, ${ }^{13}$ dan kata kalama atau takallama dengan berbagai derivasinya diulang sebanyak $75 \mathrm{kali}$, yang terdapat pada 72 ayat dalam 35 surat. ${ }^{14}$

\section{Tafsir Al-Qur'an Dalam Tinjauan Ilmu Komunikasi Modern}

Kajian tentang komunikasi dalam Al-Qur'an telah banyak dibahas oleh para ilmuan, baik dalam bentuk hasil penelitian maupun hasil pemikiran langsung berupa konsep yang dibangun atas dasar norma-norma ilmiah yang berlaku. Multi-varian hasil kajian tersebut memberikan khazanah baru dalam kajian ilmu komunikasi dalam Al-Qur’an.

Ilmu pengetahuan dapat dipahami dalam arti sederhana sebagai pengetahuan objektif, tersusun dan teratur. Ilmu pengetahuan tidak dapat dipisahkan dari agama. Sebut saja Al-Qur'an, Al-Qur'an merupakan sumber intelektualitas dan spiritualitas. Ia merupakan sumber rujukan bagi agama dan segala pengembangan ilmu pengetahuan. Ia pun menjadi sumber utama inspirasi pandangan orang Islam tentang keterpaduan ilmu pengetahuan dan agama. Manusia memperoleh pengetahuan dari berbagai sumber dan melalui banyak cara dan jalan, tetapi semua pengetahuan pada akhirnya berasal dari Allah SWT. ${ }^{15}$

Islam mengajarkan bahwa segala bentuk komunikasi dan interaksi mempunyai hubungan dengan Allah. Sehingga dalam keadaan apapun hubungan antar manusia harus dikaitkan dengan keberadaan Allah.

${ }^{11}$ Jalaluddin Rahmat, Islam Aktual, (Bandung: Penerbit Mizan, 1992), cet. ke4, h.63.

${ }^{12}$ Majma' al-Lughah al-'arabiyyah, Mu'jam al-Alfazh Al-Qur'an al-Karîm, (ttp: al-Haiah al-Mishriyyah li al-Ta’lîf wa al-Nasyr, 1975), hal.426-444.

${ }^{13}$ Majma' al-Lughah al-'arabiyyah, Mu’jam al-Alfazh Al-Qur'an al-Karîm, (ttp: al-Haiah al-Mishriyyah li al-Ta’lîf wa al-Nasyr, 1975), hal.726-727.

${ }^{14}$ Majma' al-Lughah al-'arabiyyah, Mu'jam al-Alfazh Al-Qur'an al-Karîm, (ttp: al-Haiah al-Mishriyyah li al-Ta’lîf wa al-Nasyr, 1975), hal.520-525.

${ }^{15}$ Soedewo, Ilmu Pengetahuan dan Agama, Jakarta: Darul kutub al-Islamiyyah, 2007, hal. 5. 
Dalam ilmu komunikasi, istilah komunikasi ini lebih ditekankan kepada hubungan antar manusia. Sehingga hubungan manusia dengan bukan manusia masih belum dipersoalkan dalam bidang ilmu ini.

Dalam perspektif ilmu komunikasi, eksistensi Al-Qur'an sebagai petunjuk dan pedoman hidup bagi manusia merupakan pesan (message) yang Allah sampaikan kepada manusia lewat Malaikat jibril a.s kepada Nabi Muhammad SAW dan umat manusia. Bila dilihat dari sudut pandang komunikasi seperti yang dijelaskan oleh Harold Lasswe ${ }^{16}$ dan ilmuwan komunikasi lainnya. Harold Lasswell menyatakan bahwa cara terbaik untuk menerangkan kegiatan komunikasi adalah dengan menjawab pernyataan; Who, Says, What, In Which Channel, To Whom, With What Effect, ${ }^{17}$

Komunikasi dalam pengertian Islam adalah sistem komunikasi umat Islam, pengertian itu menunjukan bahwa komunikasi Islam lebih fokus pada sistemnya dengan latar belakang filosofi (teori) yang berbeda dengan perspektif komunikasi non-Islam. dengan kata lain sistem komunikasi Islam mempunyai implikasi-implikasi tertentu terhadap makna proses komunikasi. ${ }^{18}$

Sebagaimana yang telah dibahas dalam bab sebelumnya mengenai arti komunikasi penulis memberikan kesimpulan yang mampu dikaitkan dalam bab ini adalah bahwa setiap ahli memiliki pandangan yang beragam dalam mendefinisikan komunikasi. Ilmu komunikasi merupakan ilmu sosial yang bersifat multidisipliner sehingga definisi komunikasipun menjadi banyak dan beragam. Masing-masingmemiliki penekanan arti, cakupan dan konteks yang berbeda-beda namun pada dasarnya berbagai definisi tersebut saling melengkapi dan menyempurnakan sejalan dengan perkembangan ilmu komunikasi itu sendiri.

Sebelum lebih jauh membahas mengenai ilmu komunikasi dalam AlQur’an, terlebih dahulu akan diuraikan konsep ilmu dalam Al-Qur'an. Sebagaimana diketahui bahwa Al-Qur'an merupakan firman Allah SWT yang diwahyukan kepada Nabi Muhammad SAW melalui perantara Malaikat Jibril as. untuk umat manusia.

Bila melihat konsep ilmu secara konvensional, ilmu adalah merupakan hasil akal, indra dan intuisi manusia yang diperoleh melalui hasil proses yang di-

${ }^{16}$ Onong Uchyana Efendi, Dinamika Komunikasi, Bandung: PT Remaja Rosda Karya, 20014, Cet.6, hal. 29-30.

${ }^{17}$ Who (siapa komunikatornya), Says What (pesan apa yag disamaikan), In Which Channel (media apa yang digunakan), To Whom (siapa komunikannya), with What Effect (efek apa yang diharapkannya). Onong Uchyana Efendi, Dinamika Komunikasi, Bandung: PT Remaja Rosda Karya, 20014) Cet.6, hal. 29-30.

${ }^{18}$ Andi Abdul Muis, komunikasi Islam, Bandung: PT Remaja Rosda Karya, 2001, Cet Ke I, hal. 65 . 
bangun atas dasar metode ilmiah dengan segala pirantinya. Namun bila melihat konsep ilmu dalam Al-Qur'an maka ilmu merupakan hasil derivasi dari akal manusia yang dibangun atas pemahaman tentang ayat-ayat qauliyyah (Al-Qur'an) yang merupakan firman Allah SWT, pemahaman tentang ayat-ayat kauniyyah merupakan ciptaan Allah SWT, dan pemahaman sunah/hadits yang merupakan penjelas dari Al-Qur'an.

Setelah memiliki pemahaman berdasarkan kerangka berfikir di atas, maka dapat dipahami bahwa ilmu Allah atau ilmu yang muncul dari cara pandang tersebut akan melahirkan ilmuan yang memiliki worldview bahwa ilmu Allah untuk manusia akan dibangun atas 4 (empat) pilar yaitu, Syariat Islam, Sains (ilmu pengetahuan), teknologi, dan seni. Dengan memadukan keempat pilar tersebut akan melahirkan ilmu pengetahuan terpadu, tidak dikotomi dan tidak sekuler.

Penjelasan di atas bila dikaitkan dengan kajian konsep ilmu komunikasi dalam Al-Quran, maka posisi ilmu komunikasi dan ilmu pengetahuan lainnya merupakan salah satu pilar untuk membangun ilmu pengetahuan terpadu yang tidak dikotomis. Dengan kata lain ketika membahas tentang konsep ilmu komunikasi dalam Al-Qur'an mengandung pengertian bagaimana Al-Qur'an menjelaskan konsep-konsep komunikasi yang Islami berdasarkan kandungan yang ada di dalamnya.

\section{Prinsip Komunikasi dalam Al-Qur'an}

Prinsip-prinsip komunikasi dalam Al-Qur'an semuanya berawal dari etika komunikasi yaitu: qawlan sadidan, qawlan balighan, qawlan maysuuran, qawlan layyinan, qaulan kariiman, qawlan ma'ruufan.

Dalam proses komunikasi paling tidak terdapat tiga unsur, yaitu: komunikator, media dan komunikan. ${ }^{19}$ Para pakar komunikasi juga menjelaskan bahwa komunikasi tidak hanya bersifat informatif, yakni agar orang lain mengerti dan paham, tetapi juga persuasif, yaitu agar orang lain mau menerima ajaran atau informasi yang disampaikan, melakukankegiatan atau perbuatan, dan lain-lain.

Meskipun Al-Qur'an secara spesifik tidak membicarakan masalah komunikasi, namun jika diteliti terdapat banyak ayat yang memberikan gambaran umum prinsip-prinsip komunikasi. Dalam hal ini dengan melihat kata qaul dalam konteks perintah, terdapat enam prinsip komunikasi yaitu:

${ }^{19}$ YS. Gunadi, Himpunan Istilah Komunikasi, Jakarta: Grafindo, 1998), hal.69. 


\section{a. Prinsip Qawlan Sadidan}

Di dalam Al-Qur'an kata qaulan sadidan disebutkan dua kali, pertama dalam surat An-Nisa/4: 9 yang berbunyi:

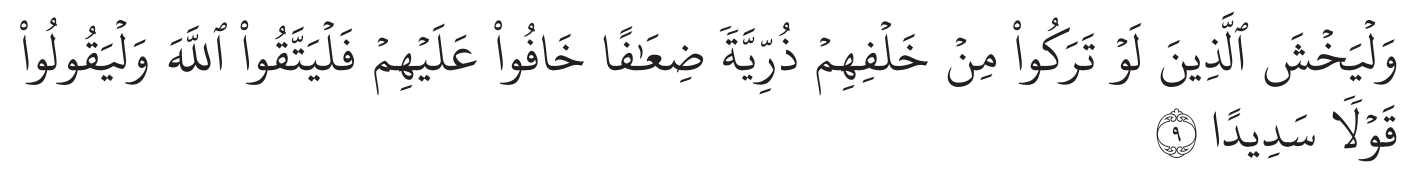

Dan hendaklah takut kepada Allah orang-orang yang seandainya meninggalkan dibelakang mereka anak-anak yang lemah, yang mereka khawatir terhadap (kesejahteraan) mereka. Oleh sebab itu hendaklah mereka bertakwa kepada Allah dan hendaklah mereka mengucapkan perkataan yang benar.

Dan kedua terdapat dalam surat Al-Ahzâb/33: 70 yang berbunyi:

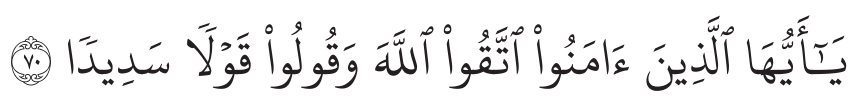

Hai orang-orang yang beriman, bertakwalah kamu kepada Allah dan katakanlah perkataan yang benar.

Hal ini diperjelas oleh Al-Qur'an yang menjelaskan bahwa Al-Qur'an mengajarkan bahwa salah satu strategi memperbaiki masyarakat adalah membereskan bahasa yag kita pergunakan untuk mengungkapkan realitas, bukan untuk menyembunyikannya. ${ }^{20}$

\section{b. Prinsip Qawlan Balighan}

Di dalam Al-Qur'an kata qawlan balighan hanya disebutkan sekali yaitu dalam surat An-Nisa/3: 63:

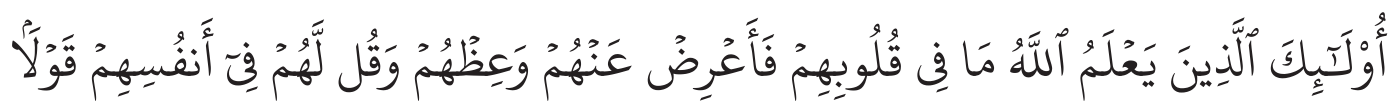

بَّلِيغًَا

Mereka itu adalah orang-orang yang Allah mengetahui apa yang di dalam hati mereka. Karena itu berpalinglah kamu dari mereka, dan berilah mereka pelajaran, dan katakanlah kepada mereka perkataan yang berbekas pada jiwa mereka.

${ }^{20}$ M. Quraish Shihab, Tafsir Al-Misbah, hal. 68-69. 


\section{c. Prinsip Qawlan Maysûra}

Istilah qawlan maysuuran hanya satu kali disebutkan dalam Al-Qur'an yang terdapat dalam surat Al-Isra/17: 28 yang berbunyi:

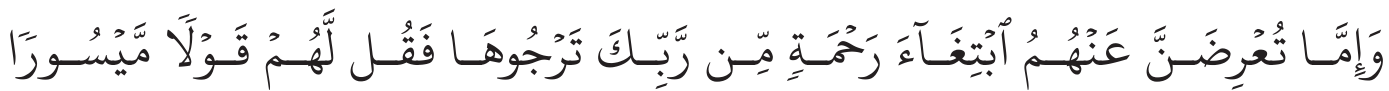

Dan jika kamu berpaling dari mereka untuk memperoleh rahmat dari Tuhanmu yang kamu harapkan, maka katakanlah kepada mereka ucapan yang pantas.

Salah satu prinsip komunikasi dalam Islam adalah setiap berkomunikasi harus bertujuan mendekatkan manusia dengan Tuhannya dan hamba-hambaNya yang lain. Islam mengharamkan setiap komunikasi yang membuat manusia terpisah dari TuhanNya dan hamba-hambaNya. Seorang komunikator yang baik adalah komunikator yang mampu menamilkan dirinya sehingga disukai dan disenangi orang lain. Untuk bisa disenangi oleh orang lain, ia harus memiliki sikap simpati dan empati. Dalam sebagian besar situasi komunikasi, simpati jauh lebih dari yang diperlukan atau bahkan diinginkan. Sedangkan empati membutuhkan kemampuan untuk melihat situasi dari sudut orang lain.

\section{d. Prinsip Qawlan Layyinan}

Istilah qawlan layyinan hanya satu kali disebutkan dalam Al-Qur'an yang terdapat dalam surat Thâhâ/20: 44 yang berbunyi:

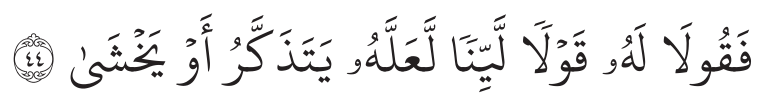

maka berbicaralah kamu berdua kepadanya dengan kata-kata yang lemah lembut, mudah-mudahan ia ingat atau takut ${ }^{21}$

Nilai dan aplikasi terdapat dalam surat Al-Hujurat/49: 13 meliputi ta'aruf dan egaliter (persamaan derajat). Agar nilai tersebut dapat dialikasikan dengan baik maka diperlukan sebuah metode.

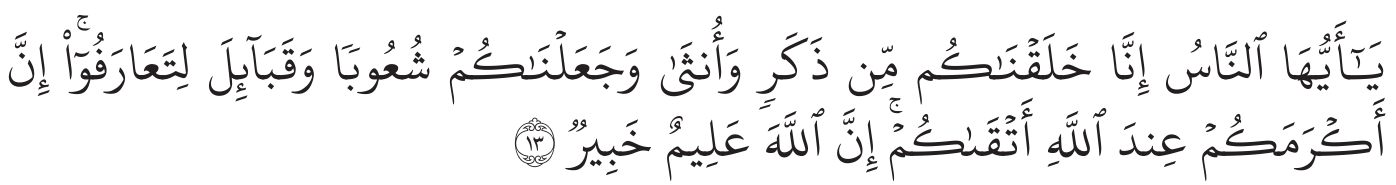

Hai manusia, sesungguhnya Kami menciptakan kamu dari seorang laki-laki dan seorang perempuan dan menjadikan kamu berbangsa-bangsa dan bersuku-suku supaya kamu saling kenal-mengenal. Sesungguhnya jilid 6 hal. 141

${ }^{21}$ Tim Depag RI, Al-Qur'an dan Tafsirnya Jakarta: Departemen Agama RI, 2009, Cet. ke-3, 
orang yang paling mulia diantara kamu disisi Allah ialah orang yang paling takwa diantara kamu. Sesungguhnya Allah Maha Mengetahui lagi Maha Mengenal.

\section{e. Prinsip Qawlan Karîman}

Dalam Al-Qur'an terdapat satu ayat yang memuat redaksi qawlan kariman, yaitu pada surat al-Isra/17: 23 yang berbunyi:

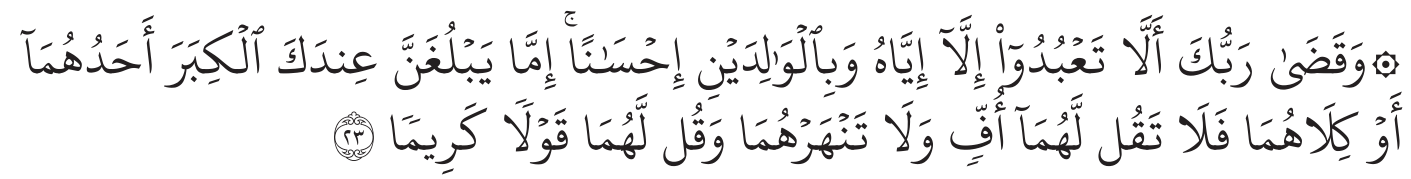

Dan Tuhanmu telah memerintahkan supaya kamu jangan menyembah selain Dia dan hendaklah kamu berbuat baik pada ibu bapakmu dengan sebaik-baiknya. Jika salah seorang di antara keduanya atau kedua-duanya sampai berumur lanjut dalam pemeliharaanmu, maka sekali-kali janganlah kamu mengatakan kepada keduanya perkataan «ah» dan janganlah kamu membentak mereka dan ucapkanlah kepada mereka perkataan yang mulia.

\section{f. Prinsip Qawlan ma'rûfan}

Selanjutnya adalah qaulan ma'rûfan. Istilah Qaulan ma'rûfan secara bahasa berarti perkataan yang ma'ruf (membangun). Dengan demikian, ia mengandung pengertian perkataan dan ucapan-ucapan yang baik, santun, dan sopan. Perkataan yang baik akan menggambarkan kearifan. Perkataan yang sama akan menggambarkan kebijaksanaan. Dan perkataan yang sopan menggambarkan sikap terpelajar dan kedewasaan. ${ }^{22}$ Berkaitan dengan perkataan yang ma'ruf ini Allah Swt. Berfirman:

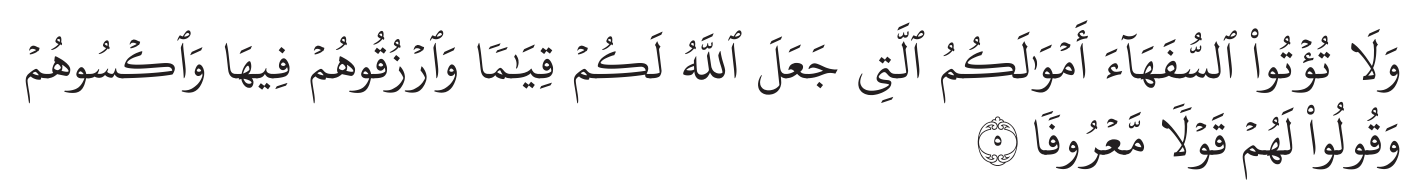

Dan janganlah kamu serahkan kepada orang-orang yang belum sempurna akalnya, harta (mereka yang ada dalam kekuasaanmu) yang dijadikan Allah sebagai pokok kehidupan. Berilah mereka belanja dan pakaian (dari

${ }^{22}$ Mawardi Labay el-Sulthani, Lidah tidak berbohong, Jakarta: Al-Mawardi Prima, 2002, hal. 47 . 
hasil harta itu) dan ucapkanlah kepada mereka kata-kata yang baik.( Q.S An-nisa/4: 5) ${ }^{23}$

Fenomena komunikasi dalam Al-Qur'an sesungguhnya telah lama ada sejak Al-Quran pertama kali turun. Namun karena perkembangan dan istilah ilmu komunikasi tersebut lahir dan berkembang di negara-negara barat, maka sentuhan komunikasi ilahiyahnya menjadi berkurang dan bahkan tidak ada sama sekali.

Keterkaitan konsep komunikasi dalam Al-Qur'an dengan konsep komunikasi dalam perspektif ilmu komunikasi adalah komunikasi merupakan salah satu kebutuhan hakiki manusia. Tanpa komunikasi individu tidak mampu membentuk masyarakat. Tanpa komunikasi juga tidak akan menimbulkan interaksi dalam kehidupan masyarakat. Oleh karena itu komunikasi menjadi Al-Quran dimulai dari hakikat manusia diciptakan di bumi yaitu untuk saling mengenal (komunikasi) antar sesama baik berlatar belakang agama, suku, bangsa, etnik, jenis kelamin dan sebagainya.

Qaulan ma'rufan lebih banyak ditunjukan kepada wanita atau orang miskin yang kurang beruntung kehidupannya, seperti anak yatim dan orang miskin. Hal ini dimaksudkan agar setiap orang dituntut untuk dapat berkomunikasi dengan pantas kepada orang lain karena perkataan yang pantas akan menimbulkan perasaan senang dan bahagia. ${ }^{24}$

\section{Allah Sang Komunikator}

Al-Qur'an adalah firman Allah yang diturunkan kepada Nabi Muhammad SAW melalui malaikat jibril yan merupakan mukjizat terbesar sepanjang sejarah manusia. Dan bagi siapa saja yang membaca Al-Quran sekalipun tidak memahami maknanya terhitung sebagai ibadah dan medapatkan ganjaran pahala yang sangat besar sebagaimana dijelaskan dalam Hadis Qudsi yang artinya: Diriwayatkan oleh Abu Said, Rasulullah SAW bersabda: "Allah berfirman: barangsiapa yang disibukkan dari memohon kepada-Ku karena membaca AlQur’an, maka Aku akan berikan dia sebaik-baik ganjaran orang yang memohon. Kelebihan firman Allah SWT dari semua perkataan adalah seperti kelebihan Allah dari semua makhluk-Nya. ${ }^{25}$ Jilid.5. hal. 114.

${ }^{23}$ Tim Depag RI, Al-Quran dan Tafsirnya, Jakarta: Departemen Agama RI, 2009, cet. Ke-3,

${ }^{24}$ M. Quraish Shihab, Tafsir Al-Misbah, hal. 85.

${ }^{25}$ Sibawaih dan Agus Dedi Putrawan, Al-Qur'an dan Prinsip Komunikasi, Jurnal Komunike, vol. 7, No.1, Juni 2015, hal.2. 
Al-Qur'an merupakan contoh konkrit bagaimana Allah selalu berkomunikasi dengan hamba-Nya melalui wahyu. Dalam hal komunikasi, Allah mengambil posisi sebagai komunikator dan "pesannya" adalah tertulis dalam Al-Quran itu sendiri dan manusia sebagai komunikasn. Karena komunikasi merupakan proses pengiriman pesan atau informasi dari komunikator kepada komunikan kemudian menghasilkan feedback atau respon.

Penulis pernah melakukan pengajian bersama Bonang Al-Bachry ${ }^{26}$ beliau menjelaskan bahwa istilah komunikasi hanyalah suatu istilah "pinjaman" untuk mengungkapkan hubungan-hubungan yang terdapat di alam semesta antara komponen-komponen semesta, yang memiliki makna atau maksud tertentu dan mengandung pengertian-pengertian tertentu di dalamnya, sehingga tidak hanya terbatas pada hubungan antar manusia. Meskipun pada bagian ini merupakan unsur utama dalam tinjauannya.

Dalam ilmu komunikasi modern tidak diambil peduli apakah gunung berbicara kepaada dahan-dahan, air dan api, langit dan manusia, binatang dan batu-batuan. Karena bidang ini hanya menganggap bahwa hanya manusia dengan Tuhan, juga tidak menjadi bidang ilmu ini.

Di dalam pengajian Al-Haq telah ada serba sedikit disinggung tentang komunikasi, dan bagaimana manusia seharusnya berkomunikasi dengan alam lingkungannya. Dan telah dibicarakan pula tentang unsur-unsur proses komunikasi yang diguakan Al-Qur'an untuk bicara kepada manusia, namun tinjauannya masih terlalu garis besar dan belum diulas secara lebih mendalam, sehingga tujuannya dan intisari pelajarannya masih samar.

Jika mengambil makna "hubungan" pada pengertian komunikasi tersebut maka sesungguhnya terdapat beberapa macam komunikasi yang dialami manusia dalam kehidupannya, yaitu:

1. Komunikasi terhadap tuhan

2. Komunikasi terhadap diri manusia itu sendiri

3. Komunikasi terhadap sesama manusia

4. Komunikasi terhadap alam semesta

Dalam pengulasan ini macam-macam komunikasi tersebut pada hakikatnya merupakan satu kesatuan yang tercakup di dalam "komunikasi terhadap

\footnotetext{
${ }^{26}$ Beliau adalah Bonang al-Bachry berasal Medan seorang guru ahli komunikasi Al-Qur’an. Beliau mendirikan komunitas engajian yang diberi nama pengajian Al-Haq dan beliau banyak membuat berbagai tulisan dari hasil pengajiannya namun tidak ada yang diterbitkan. Penulis hanya mengambil kesimpulan dari hasil pengajian dan tulisan beliau juga tulisan beberapa orang muridnya sebagai hasil dari rangkuman tiap hasil pengajian bersama murid-muridnya.
} 
Tuhan", sehingga komunikasi lainnya adalah merupakan bagian dari komunikasi tersebut. kalau hendak digambarkan dalam diagram tingkatannya akan tampak sebagai berikut:

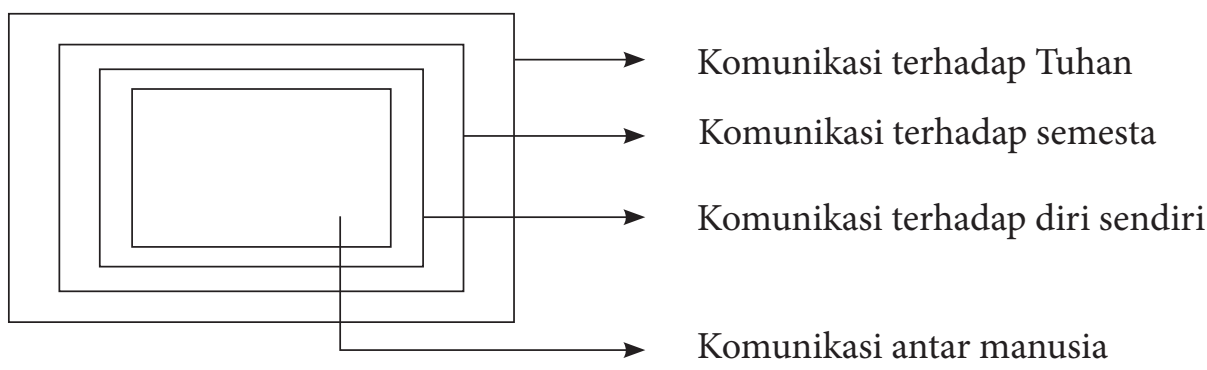

Namun demikian di dalam pengulasannya tidak harus dijelaskan secara berurut, melainkan dimulai dengan hal yang dianggap lebih mudah, karena semua jenis komunikasi itu sangat berkaitan erat. Sehingga dapati saja terjadi dalam pengulasan yang satu akan menjelaskan pula hal yang lainnya. Sedangkan tujuan yang ingin dicapai dengan penjelasan ini adalah bahwa sesungguhnya manusia dalam hidup dan kehidupannya ini adalah hanya berkomunikasi kepada Tuhan. Pemilik alam semesta ini.Jika Allah berfirman maka manusia adalah yang menerima firman itu, dan dalam bahasa yang dapat dimengerti dalam hal ini adalah, Allah adalah komunikatornya dan manusia adalah komunikannya. Dengan demikian antara Allah dan manusia telah terjadi suatu proses komunikasi. Selanjutnya dalam proses komunikasi itu harus ada yang dinamakan pesan, yaitu sesuatu yang membuat terjalinnya pengertian komunikasn terhadap kehendak komunikator yang dihadapinya, maka inilah yang dinamakan Firman.

Sekarang pesan itu tidak akan dapat diterima komunikan jika tidak disampaikan kepadanya, sehingga diperlukan alat atau sarana penyampaian yang disebut media.

Maka sekarang jelaslah sudah bahwa: jika Allah berfirman kepada manusia terdapat pula media antara Allah dan manusia itulah alam semesta ini. Jadi media dan firman tidak dapat dipisahkan. Dengan demikian hal ini dapat digambarkan dengan diagram sebagai berikut:

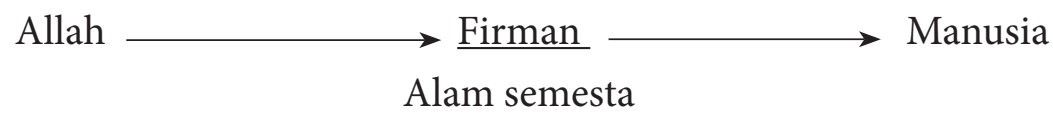

Melihat diagram yang demikian sederhana seharusnya manusia dapat segera menyaksikan siapa yang berbicara dengannya, namun karena kenyataannya alam semesta demikian luasnya sehingga seolah ada hijab yang membuat manusia terhadap Allah menjadi terpisah demikian jauh. 
Masalahnya di sini adalah bagaimana proses komunikasi itu berjalan dan sejauh mana kemampuan manusia dalam mencerna firman Allah itu. Sebagai suatu hal yang pasti berlaku dalam proses komunikasi ini adalah: "Allah berfirman dalam bahasa yang dapat dimengerti manusia, meskipun Allah mengerti segala macam bahasa yang ada.

Kalau begitu seharusnya terjadi proses sebelum pesan atau firman itu ada, yaitu proses penyusunan firman agar dimengerti oleh manusia. Di samping itu terjadi pula proses pencernaan manusia terhadap firman Allah Swt itu. Dengan demikian diagram kita dapat menjadi lebih luas:

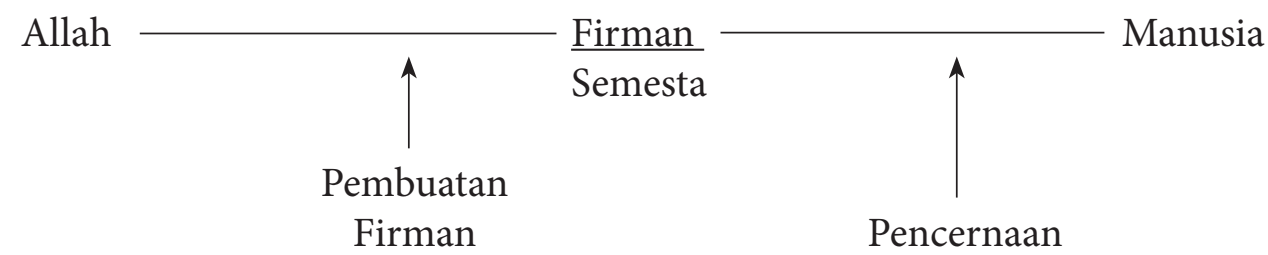

Firman

Dalam hal ini Allah telah begitu bijaksana bahwa Dia tidak hanya menjelaskan bagaimana manusia mencerna firman-Nya, tetapi juga Dia menciptakan firman-Nya dengan penjelasan yang konkrit. Hal ini tidak terdapat dalam kitab apapun kecuali Al-Qur’an.

Allah telah menjelaskan tentang bagaimana firmannya diciptakan dan menjelaskan pula cara mencernanya, maka sekarang tinggAllah bagaimana sikap manusia dalam menerima penjelasan itu, atau sikapnya setelah ia merasa jelas terhadap tujuan dan kehendak dari firman yang sampai kepadanya. Sikap ini menjadi sangat penting dalam keseluruhan proses komunikasi antara Allah dan manusia.

Jika diperhatikan komunikasi ini adalah komunikasi dua arah, yaitu antara manusia dan Allah, atau antara Allah dan manusia. Arah pertama adalah arah firman yaitu dari Allah kepada manusia yang telah tampak dengan jelas pada diagram. Maka sekarang adalah arah komunikasi manusia kepada Allah. Jika Allah telah berfirman, yang dalam hal ini Dia yang Maha mengetahui tentang firman-Nya, maka sudah barang tentu manusia tidak terbalas firman pula kepada Allah, melainkan manusia memberikan umpan balik kepada Allah dalam bentuk yang lain, yaitu melaksanakan apa yang difirmankan. Jadi dalam proses komunikasi ini akan tampak suatu pasangan yang serasi yaitu:

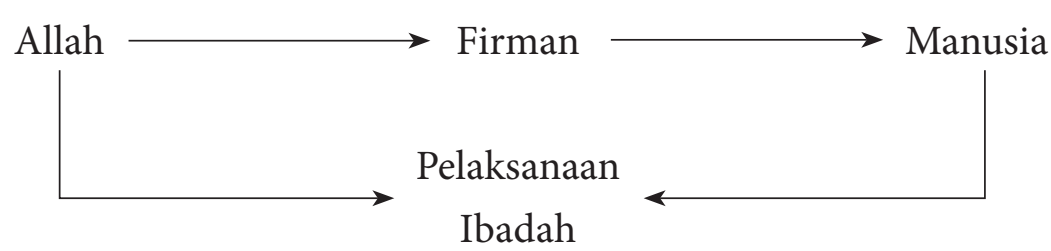


Dengan demikian dari Allah kepada manusia adalah arus firman Allah sedangkan dari manusia kepada Allah adalah arus pelaksanaan atau ibadah. Pelaksanaan ini sudah barang tentu pelaksanaan sesuai dengan firman.

Sebelum manusia memberikan umpan balik kepada Allah dalam bentuk ibadah itu, maka iman harus lebih dahulu maju ke depan untuk menerima pengertian, atau dalam perkataan lain: "iman dimaksudkan untuk menerima pengertian atau penjelasan Allah, sedangkan ibadah realisasi terhadap apa yang telah dimengerti itu". Jadi ibadah dan iman tak bisa terlepas, karena iman berarti umpan balik mengerti terhadap firman Allah Swt sedangkan ibadah adalah umpan balik realisasi iman itu yang disebut sebagai ibadah. Hal ini mengenai iman dan ibadah sebagai umpan balik akan dijelaskan pada sub bab selanjutnya. Namun sekarang telah diperoleh kelengkapan dalam proses komunikasi dua arah antara Allah dan manusia yang dapat digambarkan dalam diagram sebagai berikut:

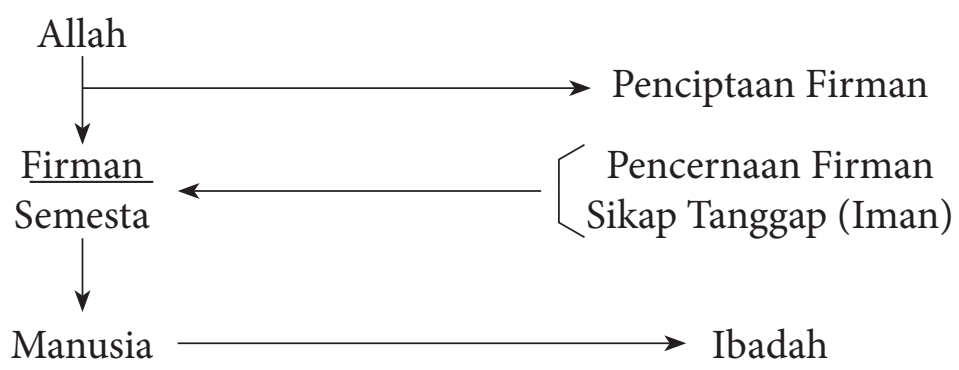

\section{Al-Qur'an dan Al-kitab sebagai Pesan dan Media}

Al-Qur'an adalah kitab komunikasi karena di dalamnya memenuhi seluruh komponen komunikasi. Menurut Onong Uchyana Effendi ${ }^{27}$ sebagaimana telah dijelaskan pada bab sebelumnya bahwa terdapat lima komponen komunikasi, yaitu: komunikator (communicator), Pesan (message), Media (media), komunikasn communicant), dan Efek (effect).

Ditinjau dari tugas nabi sebagai penerima Al-Qur'an, bahwa nabi sesuai dengan makna leksikal nabi itu sendiri berasal dari bahasa Arab, dari akar kata: nabaa, jamaknya adalah anbiya, dalam bahasa inggrisnya prophets yang berarti pembawa berita. ${ }^{28}$ Dan berita yang disampaikan oleh nabi adalah Al-Qur'an atau ayat-ayat Allah.

Prinsip dasar seorang Nabi sebagai komunikator adalah seorang yang mempunyai kemampuan intelektual yang cerdas serta (fathonah) yang dapat hal. 6.

${ }^{27}$ Onong Uchjana Efendy, Imu Komunikasi Teori dan Praktek, Bandung: Rosdakarya, 1997,

${ }^{28}$ Cyril Glasser, Ensiklopedi Islam, Jakarta: Rajagrafindo Persada, 1999, cet. Ke-2, hal. 297. 
memahami pesan yang diterima, seorang yang jujur (ash-shidqu), dan dapat dipercaya (amanah) sehingga benar-benar menyamaikan pesan tersebut dengan tidak dibuat-buat, dikurangi atau ditambahi. ${ }^{29}$ Seorang Nabi dalam menjalankan tugas menyampaikan risalah haruslah didasari perintah Allah, dengan jiwa yang tulus an cara-cara yang bersih serta penuh kesabaran. ${ }^{30}$

Dalam Al-Qur'an faktor utama dalam mencapai tujuan komunikasi di tengah-tengah keragaman komunikan adalah dengan faktor bahasa dalam arti yang seluasnya. Sebab bahasa merupakan media yang paling banyak dipergunakan dalam komunikasi dan hanya bahasa yang mampu menerjemahkan pikiran seseorang kepada orang lain. Apakah itu berbentuk idea, informasi atau opini, baik mengenai hal yang konkrit maupun abstrak, bukan saja tentang hal atau peristiwa yang terjadi pada saat sekarang, melainkan juga pada waktu yang lalu dan masa yang akan datang. ${ }^{31}$ Dengan media bahasa itu pula kita bisa mempelajari beragam ilmu, baik yang ditulis oleh para ilmuan dahulu maupun yang akan datang. Kesamaan dalam arti pemahamannya, strata pengetahuan komunikator dan komunikan, pola pendekatan persuasif yang bisa diterima semua orang untuk selanjutnya berhasil mengubah sikap dan tingkah sadar untuk mengamalkannya, semua itu menjadi target para nabi dan rosul yang hanya bisa disampaikan melalui bahasa yang dimengerti oleh umatnya. ${ }^{32}$

Secara praktis-aplikasi, Al-Qur'an menawarkan metode yang tepat dalam komunikasi, yaitu dengan cara bijaksana (hikmah), nasehat yang baik (al-maui$d z a h$ al hasanah) dan berdiskusi yang baik (al-mujadalah). ${ }^{33}$ Ketiga cara ini merupakan etika komunikasi berdasarkan Al-Qur'an yang dapat diterapkan sesuai dengan watak dan kemampuan komunikator dan komunikan.

Secara umum Al-Qur'an adalah pesan Allah SWT yang diturunkan kepada Nabi Muhammad SAW melalui perantara malaikat jibril. Al-Qur'an merupakan pedoman bagi manusia (hudan linnas) sebagai petunjuk bagi manusia akan tetapi Al-Qur'an yang secara konteks berbahasa Arab bagi masyarakat awam belumlah bisa memahami dikarenakan merekapun tidak mengerti apa arti tulisan Al-Qur'an tersebut apalagi harus mempedomaninya, hanya segelintir orang yang mampu berbahsa Arab atau yang konsen dalam hal tersebut. dengan kata lain, Al-Qur’an adalah suatu pesan untuk mengatur, mengajak atau berdakwah di jalan Allah yaitu agama Islam.

${ }^{29}$ Q.S. Al-Maidah: 99

${ }^{30}$ Q.S. Al-Muddassir: 1-7 1997, hal. 11.

${ }^{31}$ Onong Uchjana Efendy, Ilmu Komunikasi Teori dan Praktek, Bandung: Rosdakarya,

${ }^{32}$ Syaikh Mustafa Al-Maraghi, Tafsir Al-Maraghi, Terj. Bahrun Abu Bakar, dkk, Semarang: Toha Putra, 1993, Jilid V, Juz 13, hal. 126.

${ }^{33}$ Q.S. An-Nahl: 125 


\section{Iman dan Islam sebagai Respon Audiens}

Seperti telah dikatakan pada masalah komunikasi bahwa response adalah daya tanggap kita terhadap message yang telah kita lakukan pencernaan (decoding) terhadapnya di mana faktor emosi kita telah berperan terhadap message tersebut. jadi tanpa adanya response tersebut pada diri seseorang, maka message (pesan) akan kurang berarti baginya, sehingga persepsinya terhadap pesan itu akan kurang serius.

Dalam hal membaca atau menerima firman Allah Swt, seseorang memerlukan daya response terhadap wahyu yang diturunkan kepada manusia tersebut.

Sebagaimana telah diketahui bahwa Al-Qur'an berpasangan dengan Kitab, sedagkan Al-Hikmah berpsangan dengan Al-Huda, maka tidak heran pula jika untuk daya response ini diperlukan pasangan yang sepadan, yaitu Iman merespon Al-Hikmah sedangkan Islam merespon Al-Huda.

\section{Akidah dan Ibadah sebagai Respons Umpan Balik (Feedback) Audiens}

Fondasi Islam adalah tauhid (keesaan Allah), yakni menjadikan Allah SWT sebagai satu-satunya tujuan, Dzat yang haus disembah. Para ulama merinci konsep tauhid menjadi dua bagian, yaitu Tauhid Rububiyyah dan Tauhid Uluhiyyah.

Tauhid Rububiyyyah adalah meyakini bahwa hanya Allah yang menciptakan dan mengatur seluruh alam raya ini. Allahlah yang memberi rezeki, menghidupkan, dan mematikan. Oleh karena itu, hubungan antara manusia dengan Allah harus ditandai dengan kepasrahan, ketundukan dan ketaatan.

Tauhid Uluhiyyah yakni meyakini bahwa Allah-lah satu-satunya Tuhan yan berhak disembah. Hanya kepada Allah-lah segala pengabdian dan permintaan ditujukan. Tidak ada sekutu bagi-Nya. Sebagaimana kandungan kalimat thayyibah, "La Ilâha illallâh". Siapa yang berikrar dengan kalimat tersebut, berarti dia bersedia mematuhi kehendak Allah dan tidak akan mengakui kekuasaan setelah kekuasaan-Nya.

Konsep tauhid menuntun manusia untuk tetap menempatkan Alah SWT sebagai satu-satunya Tuhan. Kepada-Nyalah manusia mengabdi, segala hukum-Nya ditaati, larangan-Nya dijauhi dan perintah-Nya dijalankan. Umat manusia seluruhnya pada hakikatnya berjiwa tauhid, karenanya ajaran Islam sesuai dengan fitrah manusia yang berjiwa tauhid. 
Akidah, syariat dan akhlak dalam Islam merupakan satu kesatuan yang tidak bisa dipisahkan satu sama lain. Dalam bidang Akidah Islam mengajarkan kepercayaan atau keimanan terhadap enam hal berikut yang dikenal dengan sebutan rukun iman, yaitu:

1. Allah SWT sebagai satu-satunya Tuhan yang menciptakan dan mengatur seluruh alam semesta dan satu-satunya Tuhan yang berhak disembah dan diatuhi ajaran-Nya.

2. Para Malaikat-Nya, antara lain malaikat Jibril, Mikail, Israfil, dan Ijrail yang memiiki tugas masing-masing.

3. Kitab-kitab-Nya, yaitu: Zabur, Taurat, Injil, Al-Qur'an.

4. Para Rasul-Nya, yaitu: sejak Nabi Adam hingga Nabi Muhammd sebagai pembawa agama wahyu bagi manusia.

5. Hari Akhirat, yakni alam kehidupan sesudah mati atau setelah hancurnya alam dunia beserta isinya.

6. Qadha dan Qadar, yaitu ketentuan Allah Swt tentang segala hal bagi manusia dan makhluk lain. ${ }^{34}$

Akidah pada dasarnya merupaka suatu pondasi yang di atasnya dibagun hukum syariat. Di sini hukum syariat merupakan aktualisasi akidah. Oleh sebab itu hukum yang kuat adalah yang lahir dari akidah yang kuat. Tidak ada akidah tanpa syari'at dan tidak mungkin syari'at itu lahir jika tidak ada akidah. ${ }^{35}$

Menurut ajaran Islam, penanaman dan pengajaran mengenai akidah adalah faktor yang utama dalam membangun suatu umat karena dengan akidahlah yang nantinya menentukan keberadaan seseorang dalam hubungannya kepada Allah Swt sebagai sang Pencipta. Mengingat pentingnya pengetahuan mengenai akidah dalam kehidupan seseorang maka perlu kiranya ditanamkan sejak dini di keluarga, dan masyarakat.

Akidah haruslah memberikan warna dengan berbagai kemanfaatan hidup bagi kehidupan setiap muslim. Setiap langkah dan gerak-geriknya senantiasa dikendalikan oleh nilai-nilai akidah yang telah terhunjam kuat dalam hatinya. Nilai-nilai keimanannya memancarkan kebaikan dalam setiap aspek kehidupannya.

${ }^{34}$ Asep Syamsul M. Romli, Komunikasi Dakwah, Pendekatan Praktis, diambil dari: www. romeltea.com, (edisi pdf) pada 2 Agustus 2016. Hal. 30-33.

${ }^{35}$ Rahman Ritonga, Akidah Merakit Hubungan Manusia dengan Khaliqnya melalui Pendidikan Akidah Usia Dini, Surabaya: Amelia, 2005, hal.53. 
Begitupula dengan pesatnya perkembangan budaya serta perilaku hidup manusia yang mana di satu sisi memberi dampak positif utuk meningkatkan kemakmuran hidup manusia, akan tetapi di sisi lain juga dapat memberikan dampak yang kurang baik terhadap akidah generasi muda. Maka apabila hal ini tidak diimbangi dengan nilai-nilai akidah dalam diri, maka seorang muslim akan terpengaruh dan akan mudah melakukan hal-hal yang bertentangan dengan ajaran agama Islam serta norma-norma yang berlaku dalam masyarakat.

Masalah akidah dan keimanan merupakan hal yang sangat mendasar dalam Islam. hanya dengan akidah yang kuat, seseorang dapat menunaikan ibadah dengan baik dan dapat menghiasi dirinya dengan akhlakul karimah.

Dalam bidang syariat, Islam mengajarkan tatacara beribadah yang meliputi hubungan dengan Allah SWT dan hubungan dengan manusia. Ibadah mengandung banyak pengertian berdasarkan sudut pandang para ahli dan msksud yang dikehendaki oleh masing-masing ahli.

Ibadah adalah segala bentuk hukum, baik yang dapat dipahami maknanya (ma’qulat al-ma'na) seperti hukum yang menyangkut dengan muamalat pada umumnya, maupun yang tidak dipahami maknanya (ghairu ma'qullat alma'na), seperti bersuci (thaharah) dan shalat, baik yang berhubungan dengan angota badan seperti rukuk sujud maupun yang berhubungan dengan lidah seperti dzikir dan yang berhubungan dengan hati seperti niat. ${ }^{36}$

Apabila orang-orang beriman menginginkan ibadah mereka berhasil dengan baik dan mendapatkan pahala di sisi Allah SWT, maka mereka harus memiliki dorongan dan motivasi yag kuat untuk beribadah kepada Allah. Dalam buku "Problematika Ibadah dalam Kehidupan Manusia", diungkapkan beberapa motivasi dan dorongan beribadah, yaitu:

1. Karena Allah yang menjadi tujuan pertama dalam beribadah

2. Karena manusia sudah berjanji untuk taat kepada Allah

3. Karena bahagia yang diinginkan, manusia harus kembali ke negeri asalnya. ${ }^{37}$

Ibadah bagi seorang muslim sangatlah berpengaruh, baik di dunia maupun di akhirat. Terdapat beberapa poin penting yang menunjukan besarnya pe-

\footnotetext{
${ }^{36}$ Pengertian mengenai ibadah secara bahasa dan istilah dapat di lihat dalam: Atabik Ali dan Zuhdi Muhdlor, Kamus Kontempore Indonesia Arab, Yogyakarta: Multi Karya Grafika, tt, Cet.5, hal.1268, dan lihat pula dalam: Yusuf Al-Qardhâwî, Ibadah dalam Islam, Terj. Umar Fanani, (Surabaya: PT Biru Ilmu, 1988), h.37. lia, 1989, h.80

${ }^{37}$ Syahminan Zaini, Problematika Ibadah dalam Kehidupan Manusia, Jakarta: Kalam Mu-
} 
ngaruh positif ibadah dan amal shaleh yang dilaksanakan seorang muslim dalam hidupnya, yaitu:

a. Membentuk kehidupan dan akhlak seorang muslim dengan corak rabbani, dan menjadikannya berorientasi kepada Allah Swt dalam segala hal yang dilakukannya, ia melaksanakannya dengan niat seorang abid yang khusus, dan dengan jiwa (ruh) seorang hamba yang tekun dan tenggelam dalam ibadah, hal ini mendorongnya untuk memperbanyak amalan-amalan yang bermanfaat, mengerjakan kreativitas yang baik dan segala sesuatu yang memudahkan baginya. Serta menjalankan kehidupan secara optimal. Hal ini dapat menambahkan depositonya yang berupa amal kebaikan dan taqarrub di sisi Allah Azza wa Jalla. ${ }^{38}$ Ibadah juga mengajarkan manusia untuk mengihsankan amal (pekerjaan) duniawinya, meningkatkan kualitas dan menekuninya, selama ia mempersembahkan amal ibadah itu hanya kepada Allah Swt, demi mengharapkan ridho dan kebaikan dari-Nya.

b. Memberikan kepada seorang muslim kesatuan orientasi dan kesatuan tujuan dalam semua aspek kehidupan. Ia ridha kepada Allah Swt dalam setiap apa yang dilakukan dan yang ditinggalkannya serta menghadap (berorientasi) kepada Rabbnya dengan segenap amal usaha, duniawi dan ukhrawi, tidak ada sikap dikotomi, dilematika dan dualisme dalam kepribadian dan hidupnya. ${ }^{39}$

c. Kebahagiaan dan kesenangan hidup yang hakiki di dunia dan akhirat Allah Tảala berfirman dalam Qur'an Surat An-Nahl/16: 97.

d. Kemudahan semua urusan dan jalan keluar/ solusi dari semua masalah dan kesulitan yang dihadapi. Allah Swt berfirman dalam Qur'an Surat Ath-Thalaq/65:2-3. Ketaqwaan yang sempurna kepada Allah tidak mungkin dicapai kecuali dengan menegakkan semua amal ibadah yang wajib dan sunnah, serta menjauhi semua perbuatan yang diharamkan dan dibenci oleh Allah Swt. Allah Swt berfirman dalam Qur'an Surat Ath-Thalaq/69:4.

e. Penjagaan dan taufiq dari Allah Swt. Apabila kita menunaikan hak-hk Allah Swt dengan selalu beribadah kepada-Nya, serta menjalankan semua perintah-Nya dan menjauhi larangan-Nya, maka Allah akan selalu bersama kita dengan selalu memberi pertolongan dan taufik-Nya kepadamu.

f. Kemanisan dan kelezatan iman yang merupakan tanda kesempurnaan iman. Seseorang akan merasakan manis dan lezatnya iman apabila ia ridho Allah sebagai Tuhannya, Islam sebagai agamanya dan Nabi Muhammad

\footnotetext{
${ }^{38}$ Yusuf Al-Qardhâwy, Pengantar Kajian Islam, Jakarta: Pustaka Al-Kautsar, 1997, hal.100.
}

${ }^{39}$ Yusuf Al-Qardhâwy, Pengantar Kajian Islam, Jakarta: Pustaka Al-Kautsar, 1997, hal.101. 
Saw sebagai pembawa Risalah Allah. Karena dengan keridhaannya itu ia akan ikhlas melaksanakan ibadah dan amalan-amalan yang telah diperintahkan oleh Allah dan Rasul-Nya, tanpa ada rasa berat dan rasa terpaksa.

g. Keteguhan iman dan ketegaran dalam berpegang teguh dengan agama Allah. Allah tảala berfirman dalam Qur’an Surat Ibrâhim/14:2. Fungsi ibadah mendekatkan diri kepada Allah Swt maka dengan taufik dari Allah tảala orang yang beriman tidak akan mau berpaling dari keimanannya, karena mereka merasakan manis dan nikmatnya iman. Walaupun cobaan dan penderitaan datang silih berganti, bahkan semua cobaan tersebut menjadi ringan baginya. Gambaran inilah yang terjadi pada para sahabat Rasulullah Saw dalam keteguhan mereka sewaktu mempertahankan keimanan mereka menghadapi permusuhan dan penindasan dari orang-orang kafir Quraisy, di masa awal Rasululah Saw mendakwahkan Islam.

Dengan demikian jelaslah bahwa turunnya Al-Qur'an sebagai firman Allah kepada manusia adalah sesuai dengan pengetahuan manusia tentang komunikasi. Maka jelas sekali bahwa Al-Qur'an memang sangat sesuai dan pasti cocok dengan kemampuan manusia. Dari hasil penelitian ini maka dapat disimpulkan dengan sebuah diagram yang saling menjelaskan antara ilmu komunikasi modern dengan penjelasan Al-Qur'an yaitu:

\begin{tabular}{|l|c|}
\hline Communicator & Allah \\
\hline Konsep Dasar & $\underline{\text { Ruh }}$ \\
\hline Encoding & $\frac{\text { Qalam }}{\text { Ayat }}$ \\
\hline Message & $\frac{\underline{\text { Al-Quran }}}{\text { Al-Kitab }}$ \\
\hline Decoding & $\underline{\text { Al-Hikmah }}$ \\
\hline Response & $\begin{array}{c}\text { Al-Huda } \\
\text { Islam }\end{array}$ \\
\hline Communicant & $\begin{array}{c}\text { Manusia } \\
\text { Aqidah } \\
\text { Feedback }\end{array}$ \\
\hline
\end{tabular}

Di sini dapat dilihat kelemahan ilmu komunikasi modern tidak menjelaskan tentang pasangan-pasangan, sedangkan di dalam Al-Qur'an surat Yâ$\sin / 36: 36$ yang berbunyi: 


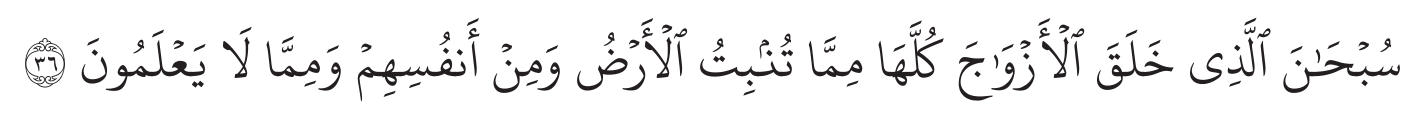

Maha Suci Tuhan yang telah menciptakan pasangan-pasangan semuanya, baik dari apa yang ditumbuhkan oleh bumi dan dari diri mereka maupun dari apa yang tidak mereka ketahui.

Dan sebagaimana firman Allah Swt di dalam surat Adz-Dzâriyât/51:49 yang berbunyi:

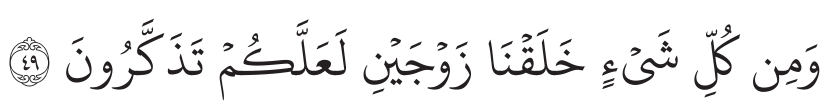

Dan segala sesuatu Kami ciptakan berpasang-pasangan supaya kamu mengingat kebesaran Allah.

Berdasarkan penjelasan di atas penulis menegaskan bahwa setiap hamba Allah yang ingin bersungguh-sungguh mempelajari Al-Qur'an sebagai Firman Allah Swt hendaklah dia mengerti lebih dahulu bahwa membaca Al-Qur'an tidak hanya semata-mata membaca yang tertulis dalam bahasa Arab itu, tetapi juga memerlukan kecerdasan ekstra untuk mendeteksi pesan yang Haq terdapat di dalamnya. Dalam surat Al-Hadid dijelaskan ayat 3 yang berbunyi:

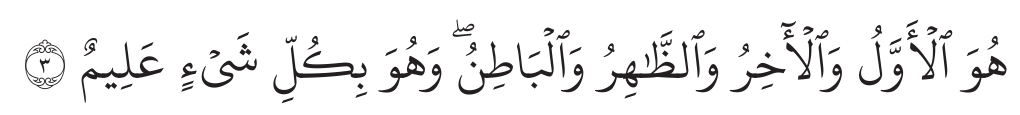

Dialah Yang Awal dan Yang Akhir Yang Zhahir dan Yang Bathin; dan Dia Maha Mengetahui segala sesuatu.

Ayat ini jelas mengatakan bahwa tanda-tanda Allah tidak hanya pada zahir saja atau pada yang bathin saja, tetapi ada pada keduanya sekaligus. Oleh sebab itu dalam membaca Al-Qur'an dengan melihat yang zhahirnya saja tidaklah baik, begitupula halnya jika dilihat dari sudut bathinnya saja. Maka melihat Al-Qur'an haruslah dari dua sudut pandangan sekaligus, yaitu yang zahir dan yang bathinnya.

Dengan penjelasan ini tidaklah heran jika melihat banyak orang yang mempelajari Al-Qur'an menjadi terpecah belah. Jika diperhatikan sebab-sebabnya adalah masing-masing melihat Al-Quran dengan sebelah mata saja. Ataupun melihat Al-Qur'an tanpa menyadari kelengkapan protes dari orang seperti ini jika dikatakan bahwa membaca Al-Qur'an adalah berdialog langsung dengan Allah dengan perantaraan Ruh dan Nur. 


\section{Penutup}

Dari keseluruhan pembahasan dalam tesis ini ada beberapa poin yang dapat dijadikan kesimpulan dan saran, yaitu:Dalam sejarah perkembangan tafsir tidak ditemukan secara spesifik penjelasan dan pemilihan aspek metodologis tafsir Al-Qur'an. Ini mungkin dikarenakan, pertama, wacana metodologi tafsir termasuk hal yang "baru didiskusikan" dan terutama dikembangkan ketika terjadi persentuhan antara tradisi Islam dengan peradaban Barat modern yang diklaim handal dalam metodologi. Kedua, para ulama mempunyai terminologi yang berbeda dalam memandang dan menilai objek kajian tafsir, termasuk dalam persoalan metodologi penafsiran Al-Quran. Karena jika dalam ilmu-ilmu alam dan fisika (natural sciences) munculnya sebuah paradigma baru cenderung menggeser atau menggantikan posisi yang lama, yang terjadi dalam ilmu-sosial humanistis, termasuk kajian ilmu-ilmu agama (tafsir) tidaklah demikian. Adanya paradigma baru dapat melengkapi kekurangan yang ada pada paradigma lama. Oleh karena itu, dalam kajian ilmu sosial termasuk kajian komunikasi keagamaan, paradigma yang digunakan adalah akumulasi asumsi, konsep atau proposisi yang diintegrasikan secara logis untuk mengarahkan pikiran dan jalannya pengkajian. Juga, klasifikasi ini bukanlah hasil dari polarisasi sosial, tetapi merupakan reproduksi intelektual.

\section{Daftar Pustaka}

Abduh, Muhammad, Tafsir al-Manâr, Kairo: Dâr Mathabi As-Syâb, t.th.

Abdurrahim, Muhammad, Penafsiran AL-Qur'an dalam Perspektif Nabi Muhammad saw, diterjemahkan oleh Rosihan Anwar, Bandung: Pustaka Setia, cet.I, 1999.

Akhmad, Abu Zakky, Tafsir Juz 'Amma, Jakarta: Rica Grapika, 1992.

Amir, M., Etika Komunikasi Massa dalam Pandangan Islam, Jakarta: Logos Wacana Ilmu, 1999

Ardianto, Elvinaro, Filsafat Ilmu Komunikasi, Bandung: Simbiosa Rekatama Media, 2007.

Arkoun, Muhammed, Kajian Kontemporer Al-Quran, Bandung: Pustaka Bandung, 1998.

Assegaf, Abd. Rachman, Studi Islam Kontekstual, Yogyakarta: Gama Media, 2005

Ayyub, Mahmud, Al-Qur'an dan Para Penafsirnya, Jakarta: Pusataka Firdaus. 1991.

Azzaino, Zuardin, Akal dan Wahyu dalam Islam, Jakarta: UI Press, cet.II, 1986.

Al-Bachri, Bonang, Dzikrul Haq Jilid.I, Jakarta: ASC Press, 1991.

, Future Paradigm, Jakarta: ASC Press, 2002. 
, Kitâb asy-Syifâ, Jakarta: ASC Press, 1992.

, Maghfirah, Jakarta: ASC Press, 2001.

, Manusia dan Dirinya, Jakarta: ASC Press, 1999.

Al-Bahsany, Abubakar Muhammad, Tafsir dan Takwil Al-Qur'an: Tafsir Ghârib Al-Quran, Surabaya: Indah, 1998.

Baljon, JMS, (Alih bahasa: A. Ni'amullah Muiz), Tafsir Qur'an, Jakarta: Firdaus, cet.III, 1993.

, (Alih bahasa: Eno Syafrudin), Al-Qur'an dalam Interpretasi Modern, Jakarta: Gaya Media Pratama, cet.I, 1990.

Bulaeng, Andi, Metode Penelitian Komunikasi Kontemporer, Yogyakarta: Penerbit Andi 2004.

Cangara, Hafied, Pengantar Ilmu Komunikasi, Jakarta: Raja Grafindo Persada, 2003.

, Pengantar Ilmu Komunikasi, Jakarta: PT. Rajagrafindo Persada, 2007.

Cardegie, Dale and Associates, inc, Sukses Berkomunikasi, Jakarta: PT. Gramedia Pustaka Utama, 2015.

Departemen Haji dan Waqaf Saudi Arabia, Al-Quran dan Terjemahnya, Madinah: Mujamma' Khâdim al-Haramain Asy-Syarîfain Raja Fahd, $1411 \mathrm{H}$.

Effendi, Onong Uchjana, Ilmu, Teori dan Filsafat Komunikasi,, Bandung: Remaja Rosdakarya, 2000.

, Ilmu Komunikasi Teori dan Praktek, Bandung: PT. Remaja Rosdakarya, 2001.

El-Sulthani, Mawardi Labay, Lidah tidak berbohong, Jakarta: Al-Mawardi Prima, 2002.

Al-Fidâ, Ismail bin Amir bin Katsir Al-Dimasyqi Abu, Tafsir Al-quran Al-Azhim Ibnu Katsir, Beirut: Dar Al-Fikr, 1412 H/ 1992 M

Glasser, Cyril, Ensiklopedi Islam, Jakarta: Rajagrafindo Persada, 1999

Hamidy, H. Zainuddin, dkk, Terjemah Hadis Shahih Bukhari Jilid I-IV, Jakarta: Wijaya, cet.XIII, 1992.

Hamka, Tafsir Al-Azhâr, Jakarta: Pustaka Panjimas, 1984.

Hardjana, Agus M., Komunikasi Intrapersonal dan Interpersonal, Yogyakarta: Kanisius, 2003.

Ismail, Abu Abdullah Muhammad ibn, al-Jamî’ ash-Shahîh, Bairut: Dâr-el Fikr, t.t.

Jalalain, Imam, Tafsir Jalalain, Bandung: Sinar Baru Algensindo, 1995, cet ke-2, jilid 1.

Al-Jufri, Abdillah Ahmad, Pelita Al-Quran Juz 30, Singapura: Pustaka Nasional Singapura, 2001. 
Karlinah, Siti, Komunikasi Massa, Jakarta: Penerbitan UT, 1999.

Khalidi, Sholah, Membedah Al-Qur'an versi Al-Quran, Surabaya: Pustaka Progressif, 1997.

Knapp, Mark, Nonverbal Communication in Human Interaction. New York: Holt, Rinehart and Winston Inc 1972.

Liliweri, Alo, Komunikasi Antarpribadi, Bandung: PT Citra Aditya Bakti, 1991

-.--, Makna Budaya dalam Komunikasi Antarbudaya, Yogyakarta: LkiS Pelangi, 2002.

Al-Maraghi, Ahmad Musthofa, Tafsir al-Maraghi, Beirut: Dâr-el Fikr, 1994.

Mahmud, Imam Abdul Halim, Al-Qur'an Bukan Al-Qur'an, Jakarta: Studia Press, cet.I, 2000.

Muhawwir, A.W, Kamus Al-Munawwir Arab-Indonesia Terlengkap, Yogyakarta: Pustaka Progressif, 1984.

Mulyana, Deddy, dkk. Ilmu Komunikasi: Sekarang dan Tantangan Masa Depan, Jakarta: Prenada Media Group, 2011. 2011.

Al-Muthalib, Abdul Majid Abdussalam, Visi dan Paradigma Tafsir Al-Qur'an Kontemporer, Bangil Jawa Timur: Al-Izzah, cet. I, 1977.

Nimmo, Dan, Komunikasi Politik: Komunikator, Pesan dan Media, Bandung: Remadja Karya, 1989.

Al-Qardhâwî, Yusuf, Ibadah dalam Islam, Terj. Umar Fanani, Surabaya: PT Biru Ilmu, 1988.

Qardhawi, Yusuf, Berinteraksi dengan Al-Quran, Jakarta: Gema Insan Press, 1999.

Qaththan, Manna', Mabâhits fi 'Ulûm al-Qurân, Riyadh: Mansyûrât al-'Ashr al-Hadîs, cet.II, t.t.

Al-Qurthubi, Tafsir Al-qurthubi, Beirut: dar Al-Fikr, 1984.

Quthb, Sayyid, Tafsir Fi Zilâlil Qurân, penerjemah: As’ad Yasin, dkk., Jakarta: Gema Insani Press, 2003.

Rafiudin, Sutrisna Sumadi, Pedoman Pendidikan Aqidah Remaja, Jakarta: Pustaka Quantum, 2002.

Rakhmat, Jalaluddin, Islam Aktual, Bandung: Mizan, 1993.

, Psikolog Komunikasi, Bandung: PT. Remaja Rosdakarya, 2002.

Ar-Razi, Muhammad bin al-Husain Fakhruddin, Tafsir ar-Razî, Beirut: Dâr-el Fikr, 1990.

Ritonga, Rahman, Akidah Merakit Hubungan Manusia dengan Khaliqnya melalui Pendidikan Akidah Usia Dini, Surabaya: Amelia, 2005 
Rosyada, Dede, Hukum Islam dan Praata Sosial, Jakarta: PT RajaGrafindo Persada, 1996

Roudhonah, Ilmu Komunikasi, Jakarta: UIN Jakarta Press, 2007

Rubin, Rebecca B, dkk. Communication Research: Strategies and Sources. Canada: Wadsworth Cengage Learning. 2010.

Sabiq, Sayyid, Nilai-Nilai Islam, Yogyakarta: Sumbangsih Offset, 1998.

Sendjaja, Sasa Djuarsa, Teori Komunikasi, Jakarta: Universitas Indonesia, 2005.

Ash-Shiddiqy, Hasbi, Kuliah Ibadah: Ibadah ditinjau dari Segi Hukum dan Hikmah Jakarta: Bulan Bintang, 1994.

Shihab, M. Quraish, Membumikan Al-Qur'an, Fungsi dan Peran Wahyu dalam Kehidupan Masyarakat, Bandung: Mizan, cet.II, 1992

, Wawasan Al-Quran, Tafsir Maudhu'i atas Perbagai Persoalan Umat, Bandung: Mizan, 1999.

, Tafsir Al-Mishbah: Pesan, Kesan, dan Keserasian Al-Quran, jakarta: Lentera Hati, 2002, vol.4.

Sudirman, Pilar-Pilar Islam: Menuju Kesempurnaan Sumber Daya Muslim, Malang: UIN Maliki Press, 2011

Suparno, Ludwig, Aspek Ilmu Komunikasi dalam Public Relations, Jakarta: PT. Indeks, 2011.

Suprapto, Tommy, Pengantar Teori dan Manajemen Komunikasi, Yogyakarta: Medpress, 2009.

Susanto, Phil Astrid, Komunikasi dalam Teori dan Praktek, Bandung: Bina Cipta, 1998.

As-Suyuthi, Jalaluddin Sebab Turunnya Ayat Al-quran, Jakarta: Gema Insani, 2008.

Sya'rawi, Syaikh Muhammad Mutawalli, Tafsir Sya'rawi, Terj: Tim terjemah Safir Al-Azhar dkk, Jakarta: Duta azhar, 2008.

Syirbasyi, Ahmad, Sejarah Tafsir Qur'an, Jakarta: Pustaka Firdaus, cet.III, 1994.

Thalhas, TH, dkk. Tafsir Fase-Paradigma Baru, Jakarta: Bale Kajian Fase, 2001.

Thobari, Muhammad bin Jarir, Jamî̀ al-Bayân 'an Ta’wîl âyât Al-Qurân. Kairo: Halabi, 1973.

Ushama, Thameem, Metodologi Tafsir Al-Qur'an, t.tp. Riora Cipta, cet.I, 2000.

West, Rihard and Lynn H. Turner, Pengantar Teori Komunikasi; Analisis dan Aplikasi, Jakarta: Penerbit Salemba Humanika, 2010.

Wijaya, A. W., Komunikasi dan Hubungan Manusia, Jakarta: PT. Bumi Aksara, 2002.

Yunus, Mahmud, Kamus Arab-Indonesia, Padang: IAIN Imam Bonjol, 1973. 
Zaini, Syahminan, Problematika Ibadah dalam Kehidupan Manusia, Jakarta: Kalam Mulia, 1989.

Al-Zamakhsyari, Abul Qasim Mahmud bin Umar al-Khawarizmi, Tafsir al-Kasysyaf 'an Haqâiq at-Tanzîl wa 'Uyûn al-Aqa al-Ta'wîl, t.d.

Al-Zuhaily, Wahbah, Tafsir Munir, Beirut: Dar al-Fikr, 1991, jilid. 15.

, Al-Quran dan Paradigma Peradaban, Yogyakarta: Dinamika, 1986.

110 Mumtäz Vol. 2 No. 1, Tahun 2018 